\title{
DIET MEDITERANIA MENURUNKAN INDEKS MASSA TUBUH, LINGKAR PINGGANG, DAN KADAR LEMAK PADA PASIEN OBESITAS
} (THE MEDITERRANEAN DIET REDUCES BODY MASS INDEX, WAIST CIRCUMFERENCE, AND BODY FAT PERCENTAGE IN OBESE PATIENTS)

\author{
$\underline{\text { Endry Septiadi }}^{1^{*}}$, Andri Andrian Rusman ${ }^{2}$, Dewi Ratih Handayani ${ }^{3}$, Iis Inayati \\ Rakhmat $^{3}$, Nur Muhamad Rohman ${ }^{4}$, Achmad Hero Prawira ${ }^{4}$, Muhammad Akmal Rais ${ }^{4}$, \\ Rifal Aldi Anugrah ${ }^{4}$ \\ ${ }^{1}$ Departemen Gizi, Fakultas Kedokteran Universitas Jenderal Achmad Yani, Cimahi, Jawa \\ Barat, Indonesia \\ ${ }^{2}$ Departemen Forensik, Fakultas Kedokteran Universitas Jenderal Achmad Yani, Cimahi, \\ Jawa Barat, Indonesia \\ ${ }^{3}$ Departemen Biokimia, Fakultas Kedokteran Universitas Jenderal Achmad Yani, Cimahi, \\ Jawa Barat, Indonesia \\ ${ }^{4}$ Program Studi Kedokteran, Fakultas Kedokteran Universitas Jenderal Achmad Yani, \\ Cimahi, Jawa Barat, Indonesia
}

Email korespondensi: endry.septiadi@lecture.unjani.ac.id

\begin{abstract}
ABSTRAK
Obesitas adalah kondisi deposit lemak tubuh berlebih ditandai dengan indeks massa tubuh (IMT) lebih dari $25 \mathrm{~kg} / \mathrm{m} 2$. Obesitas terjadi karena ketidakseimbangan pemasukan dan pengeluaran energi yang meningkatkan berat badan, lingkar pinggang, dan kadar lemak. Pasien obesitas direkomendasikan untuk menggunakan diet Mediterania oleh The European Guidelines for Obesity untuk menurunkan berat badan. Penelitian ini bertujuan untuk mengetahui pengaruh diet Mediterania terhadap IMT, lingkar pinggang, dan kadar lemak pada peserta program pelayanan penyakit kronis yang mengalami obesitas di klinik di Kota Bandung. Metode penelitian ini bersifat analitik dengan pengamatan secara kohort. Sampel diambil dengan cara consecutive sampling. Subjek pada penelitian ini adalah 57 pasien obesitas yang terbagi atas kelompok berdasarkan durasi diet Mediterania, yaitu kelompok satu bulan (K1), dua bulan (K2), dan tiga bulan (K3) yang dilakukan pemeriksaan IMT, lingkar pinggang, dan kadar lemak pada akhir setiap bulannya. Uji Anova digunakan untuk menganalisis data dilanjutkan dengan Post Hoc Duncan untuk mengetahui perbandingan setiap kelompok. Indeks massa tubuh, lingkar pinggang, dan kadar lemak mengalami penurunan yang progresif pada bulan ketiga yang menunjukkan rerata IMT yang paling rendah yaitu sebesar $26,19 \mathrm{~kg} / \mathrm{m} 2$ dengan nilai $\mathrm{p}=0,000$, rerata lingkar pinggang sebesar 86,62 $\mathrm{cm}$ dengan nilai $\mathrm{p}=0,000$, dan rerata kadar lemak yang paling rendah yaitu sebesar $32,38 \%$ dengan nilai $\mathrm{p}=0,026$ untuk kadar lemak. Lama diet Mediterania terbukti menurunkan IMT, lingkar pinggang, dan kadar lemak secara signifikan pada pasien obesitas.
\end{abstract}

Kata Kunci: diet mediterania, indeks massa tubuh, kadar lemak, lingkar pinggang, obesitas 


\begin{abstract}
Obesity is defined as excessive fat deposits and indicated by more than $25 \mathrm{~kg} / \mathrm{m} 2$ of body mass index (BMI). Obesity can occur due to an imbalance in energy intake and expenditure which makes body weight, waist circumference, and body fat percentage (BFP) increase. The Mediterranean diet has been recommended by the European Guidelines for Obesity to lose weight in obese patients. This study aims to determine the effect of duration of the Mediterranean diet on BMI, waist circumference, and BFP in the obese patients of the chronic disease service program Community at a clinic in Bandung. This research method was analytic with cohort observation. Sampling was done by consecutive sampling. Subjects in this study were 57 obese patients who were divided into groups based on the duration of the Mediterranean diet, namely the one month group (K1), the two month group (K2), and the three months group (K3), which were examined for BMI, waist circumference, and BFP at the end of each month. BMI, waist circumference, and BFP data were analyzed using the Anova test followed by Post Hoc Duncan to determine the comparison of each group.. BMI, waist circumference, and BFP experienced a significant and progressive reduction with the third month showing the lowest BMI average by $26,19 \mathrm{~kg} / \mathrm{m} 2$ with $p=0,000$ for BMI, average of $86,62 \mathrm{~cm}$ with $p=0,000$ for waist circumference, and average of $32.38 \%$ with $p=0,026$ for BFP. The duration of the Mediterranean diet has been shown to significantly reduce BMI, waist circumference, and BFP in obese patients.
\end{abstract}

Keywords: body fat percentage, body mass index, mediterranean diet, obesity, waist circumference

\section{PENDAHULUAN}

Obesitas adalah keadaan deposit lemak tubuh yang berlebih sehingga berat badan seseorang melebihi normal dan dapat membahayakan kesehatan. ${ }^{1}$ Indeks massa tubuh (IMT) lebih dari $25 \mathrm{~kg} / \mathrm{m}^{2}$ dapat dikatakan mengalami obesitas. ${ }^{2}$ Obesitas terjadi karena ketidakseimbangan asupan dan pengeluaran energi yang membuat terjadinya peningkatan berat badan, lingkar pinggang, dan kadar lemak. ${ }^{3}$ Kelebihan lemak akan diperlukan saat kekurangan gizi namun bila berlangsung dalam waktu yang lama akan terjadi deposit yang berlebihan yang menyebabkan obesitas. ${ }^{4}$ World Health Organization (WHO) menetapkan prevalensi obesitas di seluruh dunia mencapai 650 juta kasus pada tahun
2016. Usia lebih dari 18 tahun memiliki persentase obesitas sebesar $7 \%$ pada tahun 1980 dan meningkat menjadi $13 \%$ pada tahun 2015. ${ }^{1,5}$ Amerika memiliki prevalensi obesitas tertinggi, yaitu 28,3\% pada tahun 2015, disusul dengan Eropa sebanyak 22,9\% penduduk. $^{5}$ Di Indonesia, prevalensi penduduk dewasa di atas 18 tahun yang memiliki IMT lebih dari 25 $\mathrm{kg} / \mathrm{m}^{2}$ adalah $21,8 \%$, meningkat dari data tahun 2013 yaitu sebesar 14,8\% berdasarkan hasil Riset Kesehatan Dasar (Riskesdas) tahun 2018. ${ }^{6}$ Jawa barat memiliki angka kejadian obesitas sebanyak 254.760 kasus berdasarkan profil kesehatan Jawa Barat tahun 2017. ${ }^{7}$

Diet Mediterania pertama kali didefinisikan oleh Ancel Keys sebagai diet 
rendah Saturated Fatty Acid (SAFA) dan tinggi minyak nabati, diobservasi di Yunani dan Italia Selatan pada tahun $1960 .{ }^{8}$ Diet tersebut menekankan kepada konsumsi banyak Extra Virgin Olive Oil (EVOO), sayur-sayuran, buah-buahan, kacang-kacangan, biji-bijian, dan sereal, konsumsi cukup ikan, unggas, susu, dan red wine, serta konsumsi rendah telur, daging merah, dan makanan cepat saji. ${ }^{9}$ Minyak zaitun merupakan sumber lemak utama pada diet Mediterania yang mengandung tinggi asam oleat (MUFA). ${ }^{10}$ Diet tersebut terbukti baik untuk pasien obesitas dan salah satu cara untuk mendapatkan komposisi pola makan yang baik sehingga dapat menurunkan berat badan, yaitu dengan pemanfaatan diet Mediterania seperti yang direkomendasikan oleh Persatuan Endokrinologi Indonesia (Perkeni) dan European Guidelines for Obesity. 9,11

Diet Mediterania memiliki manfaat metabolik dan kesehatan termasuk penanganan obesitas yang merupakan faktor risiko terjadinya diabetes (44\%), penyakit jantung iskemik (23\%), dan kanker (7\%). ${ }^{12}$ Diet Mediterania dilaporkan dapat menurunkan kejadian obesitas. Penurunan berat badan dan IMT yang signifikan terjadi pada pasien obesitas yang melakukan diet Mediterania dengan konsumsi EVOO. ${ }^{10}$ Penelitian ini bertujuan untuk mengetahui pengaruh lama diet Mediterania terhadap IMT, lingkar pinggang, dan kadar lemak pada pasien obesitas.

\section{BAHAN DAN METODE}

Rancangan penelitian menggunakan metode analitik dengan pengamatan secara kohort untuk mengetahui hubungan lama diet Mediterania dengan status gizi berdasarkan IMT, lingkar pinggang, dan kadar lemak pada pasien obesitas selama tiga bulan.

\section{Subjek Penelitian}

Subjek penelitian ini adalah peserta program pelayanan penyakit kronis salah satu klinik di Kota Bandung yang memiliki IMT $\geq 25 \mathrm{~kg} / \mathrm{m}^{2}$ berjumlah 57 subjek. Subjek yang melakukan diet Mediterania diketahui menggunakan kuesioner Mediterranean Adherence Screener (MEDAS).

\section{Tempat dan Waktu Penelitian}

Penelitian ini dilakukan di salah satu klinik di Kota Bandung pada bulan September hingga bulan November 2020.

\section{Pemeriksaan Indeks Massa Tubuh}

Subjek melakukan pengukuran berat badan menggunakan timbangan digital dan melihat langsung hasilnya pada monitor. Tinggi badan subjek diketahui dengan pemeriksaan menggunakan microtoise dan hasil akan terlihat pada alat tersebut. Indeks massa tubuh diketahui dengan berat badan dalam kilogram dibagi oleh tinggi badan dalam meter persegi. 


\section{Pemeriksaan Lingkar Pinggang}

Lingkar pinggang subjek diketahui berdasarkan pemeriksaan menggunakan pita ukur dengan posisi subjek berdiri tegak dan bagian perut dalam keadaan rileks, selanjutnya menandai titik tengah antara tulang rusuk terbawah dengan tonjolan tulang iliaka, lalu menempatkan pita ukur pada daerah yang telah ditandai melingkari pinggang secara horizontal. Hasil pengukuran akan terlihat pada pita ukur.

\section{Pemeriksaan Kadar Lemak}

Kadar lemak subjek diketahui berdasarkan pemeriksaan dengan menggunakan bioelectrical impedance analysis (BIA). Pemeriksa menekan tombol
"SET" untuk menyalakan alat lalu memasukkan data jenis kelamin, berat badan, tinggi badan, dan usia pada alat. Subjek menggenggam alat lalu menekan tombol "start" hingga pengukuran selesai dan hasilnya akan terlihat pada monitor.

\section{Skor Mediterranean Adherence}

\section{Screener (MEDAS)}

Pada penelitian ini, digunakan kuesioner MEDAS seperti yang ada pada tabel 1 untuk mengetahui bahwa subjek telah menjalankan diet Mediterania. Skor lebih dari 9 menyatakan bahwa subjek telah melaksanakan diet Mediterania sedangkan skor di bawah 9 menyatakan subjek tidak menjalankan diet Mediterania. 
Tabel 1 Mediterranean Adherence Screener (MEDAS)

\begin{tabular}{lcccc}
\hline No. & Pertanyaan & Ya & Tidak & Sko \\
& & $(\mathbf{1})$ & $(\mathbf{0})$ & $\mathbf{r}$
\end{tabular}

1. Apakah Anda menggunakan minyak zaitun sebagai sumber lemak pada makanan Anda?

Apakah Anda mengonsumsi 4 sendok atau lebih minyak zaitun per

2. hari?

2. (Termasuk minyak yang digunakan untuk menggoreng bahan makanan dan makanan di luar rumah)

3. Apakah Anda mengonsumsi 5 porsi atau lebih sayuran per hari?

$(1$ porsi $=80 \mathrm{~g})$

Apakah Anda mengonsumsi 3 porsi atau lebih buah-buahan per

4. hari?

( 1 porsi $=80 \mathrm{~g}$ atau $150 \mathrm{ml}$ jus buah alami $)$

5. Apakah Anda mengonsumsi kurang dari 1 porsi daging per hari?

$(1$ porsi $=100-150 \mathrm{~g})$

Apakah Anda mengonsumsi kurang dari 1 porsi mentega, margarin,

6. atau krim per hari?

$(1$ porsi $=12 \mathrm{~g})$

Apakah Anda mengonsumsi kurang dari 1 porsi minuman manis

7. atau berkarbonasi per hari?

(tidak termasuk minuman 'diet')

8. Apakah Anda meminum 10 unit atau lebih wine per minggu?

Apakah Anda mengonsumsi 3 porsi atau lebih kacang polong per

9. minggu?

$(1$ porsi $=150 \mathrm{~g})$

Apakah Anda mengonsumsi 3 porsi atau lebih ikan atau kerang per

10. minggu?

( 1 porsi $=100-150 \mathrm{~g}$ ikan atau 200g kerang)

11. Apakah Anda mengonsumsi kurang dari 3 porsi roti, permen, kue

kering, dan es krim per minggu?

Apakah Anda mengonsumsi 3 porsi atau lebih kacang tanah per

12. minggu?

$(1$ porsi $=30 \mathrm{~g})$

Apakah Anda makan daging putih atau unggas (misalkan daging

13. ayam) lebih sering daripada daging merah (misalkan daging sapi

atau kambing) atau daging olahan setiap minggu?

Apakah Anda mengonsumsi saus yang dibuat dengan tomat atau

14. bawang, daun bawang atau bawang putih dan dengan minyak zaitun

2 kali atau lebih dalam seminggu?

Total Skor

Keterangan :

Total skor $\geq 9=$ menentukan kriteria diet Mediterania

Total skor $\leq 9=$ tidak menentukan kriteria diet Mediterania

Dikutip dari : Papadaki A, $2018^{13}$

\section{Analisis Data}

Uji normalitas dilakukan terlebih dahulu pada data IMT, lingkar pinggang, dan kadar lemak pada bulan pertama, kedua, dan ketiga menggunakan Kolmogorov Smirnov karena jumlah data lebih dari 50 kemudian melakukan uji homogenitas dengan uji Levene untuk selanjutnya data terdistribusi normal 
dianalisis dengan uji Anova dilanjutkan dengan uji Post Hoc Duncan untuk mengetahui hubungan durasi diet Mediterania dengan IMT, lingkar pinggang, dan kadar lemak pada pasien obesitas. Analisis dilakukan dengan menggunakan salah satu program statistik SPSS versi 24.0.

\section{Aspek Etik Penelitian}

Penelitian ini telah disetujui oleh Komisi Etik Universitas Jenderal Achmad Yani dengan nomor 030/UM2.09/2020.

\section{HASIL DAN PEMBAHASAN}

Penelitian ini dilakukan untuk mengetahui hubungan lama diet Mediterania dengan status gizi berdasarkan IMT, lingkar pinggang, dan kadar lemak pada 57 peserta program pelayanan penyakit kronis yang mengalami obesitas. Subjek dibagi atas tiga kelompok, yaitu kelompok yang mengaplikasikan diet Mediterania selama satu bulan (K1), dua bulan (K2), dan tiga bulan (K3) untuk selanjutnya dilakukan pemeriksaan IMT, lingkar pinggang, dan kadar lemak untuk masing-masing kelompok.

Hasil penelitian dianalisis menggunakan uji normalitas Kolmogorov Smirnov karena subjek berjumlah lebih dari 50 dan menunjukkan semua data terdistribusi normal ( $p>0,05)$ sehingga untuk mengetahui hubungan lama diet Mediterania dengan IMT, lingkar pinggang, dan kadar lemak digunakan uji
Anova kemudian dilakukan uji Post Hoc Duncan.

\section{Karakteristik Subjek Penelitian}

Berdasarkan hasil penelitian diperoleh rerata usia subjek adalah 55,68 tahun. Median 55,00 dengan standar deviasi 9,68. Usia paling muda subjek adalah 34 tahun sedangkan usia tertua subjek adalah 80 tahun. Dari hasil estimasi interval dapat disimpulkan bahwa rerata usia pasien adalah 53,11 tahun sampai dengan 58,25 tahun yang dapat dilihat pada tabel 2 .

Jenis kelamin pada penelitian menunjukkan bahwa mayoritas subjek adalah perempuan yaitu sebanyak 37 subjek atau 64,9\%, sedangkan laki-laki sebanyak 20 subjek atau $35,1 \%$ yang dapat dilihat pada tabel 2 .

\section{Hubungan Lama Diet Mediterania dengan Indeks Massa Tubuh}

Hasil uji Anova dilanjutkan dengan uji Post Hoc Duncan diperoleh bahwa K2 dan K1 tidak berbeda secara signifikan. Diet Mediterania selama dua bulan memiliki rerata penurunan IMT lebih besar dibandingkan diet Mediterania satu bulan. Kelompok diet Mediterania tiga bulan (K3) berbeda signifikan dengan dua kelompok lainnya dan memiliki rerata IMT paling rendah diantara ketiga kelompok yaitu sebesar $26,19 \mathrm{Kg} / \mathrm{m}^{2}$ seperti yang terlihat pada tabel 2. Data menunjukkan diet Mediterania selama tiga bulan paling berpengaruh dalam menurunkan IMT. 
Diet Mediterania memiliki efek $\beta$ oksidasi asam lemak yang tinggi sehingga menurunkan kadar TGA karena akan lebih cepat dijadikan ATP untuk energi dibanding menjadi deposit lemak yang berakibat terjadinya peningkatan berat badan. ${ }^{11,14}$ Obesitas menyebabkan remodelling jaringan sebagai respon terhadap apoptosis sel lemak yang berdampak pengeluaran sitokin proinflamasi sehingga terjadilah resistensi insulin pada pasien obesitas. ${ }^{15,16}$

Diet Mediterania menurunkan konsumsi karbohidrat simpleks yang dapat membuat penurunan lipogenesis untuk menghambat penumpukan TGA di jaringan adiposa sehingga tidak terjadi pertambahan IMT pada subjek. ${ }^{15}$

\section{Hubungan Lama Diet Mediterania dengan Lingkar Pinggang}

Hasil uji Anova dilanjutkan dengan uji Post Hoc Duncan diperoleh bahwa diet K1, K2, K3 berbeda secara signifikan. Antara 1 bulan dengan 2 bulan diet Mediterania, lebih baik diet Mediterania 2 bulan karena memiliki rerata penurunan lebih besar dibandingkan diet Mediterania 1 bulan. Sementara, diet Mediterania 3 bulan memiliki rerata lingkar pinggang paling rendah yaitu sebesar $86,62 \mathrm{~cm}$ seperti yang terlihat pada tabel 2. Diet Mediterania tiga bulan paling berpengaruh untuk menurunkan lingkar pinggang.

Karbohidrat yang dikonsumsi cenderung meningkatkan lemak viseral yang terdapat pada rongga perut dan merangsang lipogenesis hepatic de novo akibat kegagalan kerja hormon leptin yang apabila terjadi terus-menerus dapat menyebabkan akumulasi asam lemak pada sel lemak sehingga terjadi peningkatan lingkar pinggang. Akumulasi asam lemak dalam sel lemak menyebabkan resistensi insulin yang meningkatkan lipolisis dan memproduksi asam lemak bebas yang menginduksi peningkatan sintesis TGA pada hati yang selanjutnya akan menuju sirkulasi sehingga terjadi hipertrigliseridemia berakibat penumpukan lemak viseral. Penurunan konsumsi karbohidrat dan konsumsi MUFA dan PUFA Omega 3 yang didapatkan dari konsumsi ikan dan minyak zaitun pada diet Mediterania dapat menurunkan lipogenesis dan resistensi insulin sehingga terjadi penurunan lingkar pinggang. ${ }^{17}$

\section{Hubungan Lama Diet Mediterania dengan Kadar Lemak}

Hasil uji Anova dilanjutkan dengan uji Post Hoc Duncan diperoleh bahwa K1 memiliki penurunan kadar lemak yang tidak signifikan dibandingkan dengan kelompok yang menjalani diet Mediterania selama dua bulan (K2). Kelompok yang menjalani diet Mediterania selama tiga bulan (K3) memiliki rerata kadar lemak yang paling rendah yaitu sebesar $32,38 \%$ dibanding kedua kelompok lainnya yang menandakan diet Mediterania selama tiga 
Septiadi, E : Diet Mediterania Menurunkan Indeks Massa Tubuh...

bulan lebih baik dalam menurunkan kadar lemak seperti yang terlihat pada tabel 2 .

Kandungan PUFA Omega 3 yang direkomendasikan pada diet Mediterania dapat menghambat lipogenesis yang dalam pembentukan TGA akan terhambat sehingga kadar lemak menurun. Kandungan monounsaturated fatty acids (MUFA) yang terdapat pada minyak zaitun yang direkomendasikan pada diet Mediterania dapat meningkatkan $\beta$ oksidasi lemak sehingga asam lemak lebih cepat dijadikan adenosine triphospate (ATP) untuk energi dibanding disimpan dalam bentuk trigliserida (TGA). ${ }^{18,19}$

Konsumsi buah-buahan, sayur-sayuran yang tinggi akan serat dapat menurunkan kadar lemak melalui peningkatan buang air besar, menurunkan waktu transit lemak, meningkatkan ekskresi lemak, menurunkan asupan energi, dan meningkatkan sensitivitas insulin. Penurunan waktu transit lemak dan peningkatan ekskresi lemak disertai dengan peningkatan sensitivitas insulin yang membuat glukosa yang ada di dalam peredaran darah akan ditransportasikan kepada sel-sel tubuh untuk dijadikan energi sehingga akan menurunkan deposit lemak. ${ }^{20}$

Dampak antiinflamasi dan antioksidan pada buah-buahan, sayuran, dan biji-bijian menurunkan risiko resistensi insulin yang diakibatkan oleh pengeluaran sitokin proinflamasi didukung dengan konsumsi asam lemak tak jenuh dari minyak zaitun yang meningkatkan $\beta$-oksidasi lemak sehingga dapat menurunkan deposit lemak. $^{21}$

Tabel 2 Data hasil penelitian

\begin{tabular}{|c|c|c|c|c|c|}
\hline & Baseline $(n=57)$ & K1 $(n=19)$ & K2 $(n=19)$ & K3 $(n=20)$ & p \\
\hline Usia (tahun) & 55,68 & & & & \\
\hline Laki-laki & $20(35,1 \%)$ & & & & \\
\hline Perempuan & $37(64,9 \%)$ & & & & \\
\hline Rerata IMT $\left(\mathrm{kg} / \mathrm{m}^{2}\right)$ & 27,6 & 27,41 & 27,24 & 26,19 & 0,000 \\
\hline $\begin{array}{l}\text { Rerata lingkar pinggang } \\
(\mathrm{cm})\end{array}$ & 93,2 & 92,83 & 90,15 & 86,62 & 0,000 \\
\hline Rerata kadar lemak (\%) & 35,9 & 35,07 & 34,53 & 32,38 & 0,026 \\
\hline
\end{tabular}

Keterangan :

K1 : Kelompok yang menjalankan diet Mediterania selama satu bulan

K2 : Kelompok yang menjalankan diet Mediterania selama dua bulan

$\mathrm{K} 3$ : Kelompok yang menjalankan diet Mediterania selama tiga bulan

\section{Keterbatasan Penelitian}

Keterbatasan dalam penelitian ini yaitu penggunaan kuesioner MEDAS yang tidak dapat mengetahui kepatuhan pola makan dari subjek secara pasti, sedikitnya subjek yang mengonsumsi minyak zaitun yang menjadi makanan yang sangat disarankan pada diet Mediterania karena biaya yang 
Septiadi, E : Diet Mediterania MenurunkaIndeks Massa Tubuh...

mahal, dan kondisi pandemi COVID-19 menjadi salah satu kendala yang membuat komunikasi peneliti dengan subjek terganggu.

\section{KESIMPULAN}

Berdasarkan hasil penelitian dapat disimpulkan bahwa subjek penelitian rerata berusia 55,68 tahun dengan mayoritas jenis kelamin perempuan. Diet Mediterania dapat menurunkan IMT, lingkar pinggang, dan kadar lemak secara progresif selama 3 bulan. Diet Mediterania selama tiga bulan memiliki hasil penurunan yang lebih baik dibandingkan dengan satu bulan dan dua bulan.

\section{KONFLIK KEPENTINGAN}

Tidak terdapat konflik kepentingan dalam jurnal ilmiah yang ditulis.

\section{UCAPAN TERIMA KASIH}

Dalam penyusunan jurnal ilmiah ini tidak terlepas dari bantuan, saran, dan bimbingan dari berbagai pihak. Oleh karena itu pada kesempatan ini penulis ingin mengucapkan terima kasih kepada Lembaga Penelitian dan Pengabdian Masyarakat (LPPM) Universitas Jenderal Achmad Yani yang telah memfasilitasi penelitian, Dekan beserta staf Fakultas Kedokteran Universitas Jenderal Achmad Yani, staf Klinik yang selalu membantu dalam kegiatan penelitian, dan seluruh pasien obesitas Komunitas program pelayanan penyakit kronis yang telah bersedia menjadi subjek penelitian, orang tua dan para sahabat yang selalu memberi dorongan kepada penulis dalam menyelesaikan jurnal ilmiah ini.

\section{DAFTAR PUSTAKA}

1. Kementrian Kesehatan Republik Indonesia Direktorat Jenderal Pelayanan Kesehatan (DITJEN YANKES). Obesitas. (Available from : http://yankes.kemkes.go.id/readobesitas-8156.html) 2019. [accessed April 27th 2020]

2. Jeong U, Jae H, Ju S, Yong I, TaeHyung K, Seong Y et al. Comparison of World Helth Organization and AsiaPacific Body Mass Index Classifications in COPD Patients. International Journal of COPD 2017; 12: $2465-75$

3. Panuganti K, Kshirsagar R. Obesity. (Available from https://www.ncbi.nlm.nih.gov/books/N BK459357/) 2019. [accessed April 6th 2020]

4. Redinger RN. The Pathophysiology of Obesity and Its Clinical Manifestations. Gastroenterology and Hepatology 2007;3:11.

5. Chooi YC, Ding C, Magkos F. The Epidemiology of Obesity. Metabolism Clinical and Experimental 2019;92:610.

6. Kementerian Kesehatan Republik Indonesia (Kemenkes). Hasil Utama 
Septiadi, E : Diet Mediterania Menurunkan Indeks Massa Tubuh...

Riset Kesehatan Dasar. 2018.

7. Dinas Kesehatan Provinsi Jawa Barat. Profil Kesehatan Jawa Barat. 2017.

8. Davis C, Bryan J, Hodgson J, Murphy K. Definition of the Mediterranean Diet : A Literature Review. Nutrients 2015;7:9139-53.

9. Yumuk V, Tsigos $\mathrm{C}$, Fried $\mathrm{M}$, Schindler K, Busetto L, Micic D, et al. European Guidelines for Obesity Management in Adults. Obes Facts 2015;8:402-24.

10. Mazzocchi A, Leone L, Agostoni C, Pali-Scholl I. The Secret of the Mediterranean Diet. Does [Only] Olive Oil Matter?. Nutrients 2019;11:2941.

11. Perkumpulan Endokrinologi Indonesia (Perkeni). Pedoman Pengelolaan dan Pencegahan Diabetes Melitus Tipe 2 Dewasa di Indonesia. 2019.

12. Kementerian Kesehatan Republik Indonesia. Panduan Pelaksanaan Gerakan Nusantara Tekan Angka Obesitas (GENTAS). 2017.

13. Papadaki A, Johnson L, Toumpakari Z, England C, Rai M, Toms S, et al. Validation of the English Version of the 14-Item Mediterranean Diet Adherence Screener of the PREDIMED Study, in People at High Cardiovascular Risk in the UK. Nutrients 2018;10:138.

14. Goulet J, Lapointe A, Lamarche B, Lemieux S. Effect of a Nutritional
Intervention Promoting the Mediterranean Food Pattern on Anthropometric Profile in Healthy Women from the Quebec City Metropolitan Area. European Journal of Clinical Nutrition 2007;61:1293300.

15. Olszewska M, Groth D, Szczerbinski L, et al. Epidemiology and Pathogenesis of Obesity. Post N Med 2018; 31(2): 102-5.

16. Pouwels S, Topal B, Knook MT, et al. Interaction of Obesity and Atrial Fibrilation: An Overview of Pathophysiology and Clinical Management. Expert Review of Cardiovascular Therapy 2019; 71(1): 69-84.

17. Anggraini DI, Labibah Z. Diet Mediterania dan Manfaatnya terhadap Kesehatan Jantung dan Kardiovaskular. Majority 2016;5(3):188-94.

18. Raatz SK, Conrad Z, Johnson LK, Picklo MJ, Jahns L. Relationship of the Reported Intakes of Fat and Fatty Acids to Body Weight in US Adults. Nutrients 2017;9:438.

19. Hotta K, Nakamura M, Nakata $Y$, Matsuo T, Kamohara S, Kotani K. INSIG2 gene rs7566605 polymorphism is associated with severe obesity in Japanese. J Hum Genet 2008;53:857862 
Septiadi, E : Diet Mediterania MenurunkaIndeks Massa Tubuh...

20. Alemany MF, Jimenez NM, Nestares T, Cosic MB, Aranda P, Aparicio VA. Mediterranean diet, tobacco consumption and body composition during perimenopause. The FLAMENCO project. Maturitas 2020;137:30-6.
21. Boghossian NS, Yeung EH, Mumford SL, Zhang C, Gaskins AJ, Wende JW, et al. Adherence to the Mediterranean Diet and Body Fat Distribution in Reproductive Aged Women. Eur J Clin Nutr 2013;67(3):289-94. 